Crop Breeding and Applied Biotechnology 15: 227-234, 2015

Brazilian Society of Plant Breeding. Printed in Brazil

\title{
ARTICLE
}

http://dx.doi.org/10.1590/1984-70332015v15n4a39

\section{Genetic parameters and selection of Brachiaria decumbens hybrids for agronomic traits and resistance to spittlebugs}

Rogério Gonçalves Mateus ${ }^{1}$, Sanzio Carvalho Lima Barrios ${ }^{2 *}$, Cacilda Borges do Valle², José Raul Valérioº, Fabrícia Zimermann Vilela Torres ${ }^{2}$, Lucas Bearari Martins ${ }^{1}$ and Pedro Nelson Cesar do Amaral ${ }^{1}$

Received 25 March 2014

Accepted 11 September 2015

\begin{abstract}
The objective of this work was to estimate genetic parameters for agronomic traits and resistance to spittlebugs in $B$. decumbens hybrids and to select the ones with best performance. For that, 324 hybrids were evaluated in field plots for agronomic traits and in the greenhouse for resistance to spittlebugs. Genetic variability amongst the hybrids was observed for all traits analyzed. The heritability estimates between genotypes means were higher than 0.52 for all agronomic traits and 0.98 and 0.99 for nymphal survival and nymphal period duration respectively. Hybrids with better performance than cultivar Basilisk for each individual trait were identified and also through a selection index combining all traits. Assigning weights to the different traits in the selection index did not significantly alter the rank for superior hybrids. Those were selected to continue on to the next phases of the breeding program.
\end{abstract}

Key words: Apomixis, forage breeding, recurrent selection, selection index.

\section{INTRODUCTION}

Brachiaria pastures are the basis of animal production in the tropics and in Brazil since they provide means of producing beef and milk in acid and poor soils. These forages also played a major role in bringing progress to some regions through the establishment of seed production industries. Brazil is the largest producer and exporter of tropical forage seeds and presently over $70 \%$ of the seed sold in Brazil are of Brachiaria cultivars (Valle et al. 2009) and $83.8 \%$ of the seed production areas in 2011/2012 were planted to these cultivars (Jank et al. 2014). Despite the importance of this genus, there are still few cultivars available commercially. Among the species widely used, $B$. decumbens has a sole cultivar, cv. Basilisk, and it is planted to millions of hectares and comprises about $30 \%$ of all the seed exported by Brazil to all of Latin America (José 2012). According to Keller-Grein et al. (1996), this cultivar is the best known and mostly widely used throughout the world. Its excellent adaptation to poor, acid soils and its palatable forage production in pastures that withstand high grazing pressure somehow counteracts its susceptibility to pasture spittlebugs (Valério et al. 1996) and animal photosensitization (Lascano and Euclides 1996).
Breeding of $B$. decumbens was restricted to the use of $\mathrm{cv}$. Basilisk as a pollen donor in interspecific crosses with $B$. ruziziensis until the recent success of the tetraploidization of sexual $B$. decumbens accessions from the germplasm (Simioni and Valle 2009). The sexual duplicated plants allowed hybridization and exploitation of the variability locked by apomixis, thus widening the genetic basis of the species. These hybrids represent a unique opportunity of selecting genitors for new recombination or identification of superior apomictic hybrids as candidates for new cultivars of $B$. decumbens.

This work had the objective of estimating genetic parameters for agronomic traits and resistance to spittlebugs in $B$. decumbens hybrids and to select the ones with best performance for the next phases of the breeding program.

\section{MATERIAL AND METHODS}

Three artificially tetraploidized sexual plants (Simioni and Valle 2009) were initially crossed to the apomictic cv. Basilisk. From these crosses, 457 intraspecific hybrids were obtained which constituted the base population (cycle zero) of the $B$. decumbens breeding program. 324 hybrids

Universidade Estadual de Mato Grosso do Sul, Unidade de Aquidauana, Rod. Aquidauana-UEMS, km 12, C.P. 25, 79.200-000, Aquidauana, MS, Brazil.

${ }_{2}$ Embrapa Gado de Corte, Av. Rádio Maia, 830, Zona Rural, 79.106-550, Campo Grande, MS, Brazil. *E-mail: sanzio.barrios@embrapa.br 
from this population were selected (mass selection) based on plant vigor and production potential and these were the genotypes considered in this work, together with the parental materials: $B$. decumbens $\mathrm{cv}$. Basilisk (male genitor) and D24/2, D24/27 e D24/45 (female genitors). Also, $B$. brizantha $\mathrm{cv}$. Marandu, cv. Xaraés and BRS Piatã were used as check varieties.

The experiment was conducted at Embrapa Beef Cattle Research Center (lat $20^{\circ} 27^{\prime} \mathrm{S}$, longi $54^{\circ} 37^{\prime} \mathrm{W}$ and alt 530 $\mathrm{m}$ asl), located in Campo Grande, MS. The soil type was a dystrophic Purple Oxisol (Embrapa 1999). The climate is classified as an AW tropical wet or savanna type, according to Köppen, characterized by a well defined dry season in the winter and a rainy summer, with average annual rainfall of $1469 \mathrm{~mm}$. The average annual temperature is $23{ }^{\circ} \mathrm{C}$.

The experiment was established on January 19th, 2012 by cuttings (clonal propagation) taken from the base population. The experimental design was a simple lattice $18 \times 18$ with two replications and five plants per plot. The controls and the parental materials were placed in an incomplete additional block, randomly placed in each replication. The spacing was $0.5 \mathrm{~m}$ between plants in the line and $1 \mathrm{~m}$ between lines with $2.5 \mathrm{~m}^{2}$ experimental plot. The external border had two lines of Panicum maximum (Jacq) cv. Massai.

After a standardization clipping done on April 10th, 2012, the plots were subjected to seven clippings: two in the dry season (clippings 1 and 2: July 6, and October 2, 2012, respectively) and five in the rainy season (clippings 3 to 7 on: November 5; December 11, 2012; January 17; March 13; and May 7, 201, respectively). The intervals between clippings were established respecting the full development of the plants during the season, so that there were less time between rainy season clippings and more time between the two dry season ones.

Before each clipping, the stand was evaluated (number of plants per plot) as to correct the data in relation to the initial stand. Clippings were done with a coastal trimmer no lower than $10 \mathrm{~cm}$. The whole plot of five plants was mowed and the biomass weighed in a field scale to determine total green weight per plot. A sample of about 300 grams was removed from clippings 1, 2, 3 and 5 (two dry and two wet season clippings) and taken to the cold chamber for further separation into leaves, sheath + stems and dead matter. After separation, samples were put in a drying chamber with forced ventilation, at $65^{\circ} \mathrm{C}$ for 72 hours, to determine dry weight of each morphological component. For the other clippings a sample of about 300 grams was taken to determine dry biomass percentage and total biomass.
For the clippings with morphological separation, six agronomic traits were evaluated: field green weight (FGW, $\mathrm{kg} / \mathrm{ha}$ ); total dry biomass production (TDM, $\mathrm{kg} \mathrm{ha}^{-1}$ ); leaf dry biomass production (LDM, $\mathrm{kg} \mathrm{ha}^{-1}$ ); leaf percentage $(\% \mathrm{~L})$; leaf: stem ration (LSR) and regrowth capacity (Reg). Regrowth was evaluated seven days after each clipping and it was a function of visual density (1: up to $20 \%$ of regrown tillers; $2: 20 \%-40 \% ; 3: 40 \%-60 \% ; 4: 60 \%-80 \%$ and 5 : more than $80 \%$ ) and speed of regrowth in height (low, medium and high), and the final regrowth score is a combination of the two scores: density x speed according to Basso et al. (2009). For all other clippings the traits evaluated were FGW, TDM and Reg.

Besides the field evaluation, resistance to spittlebugs was evaluated in the greenhouse according to the methodology described by Lapointe et al. (1992) and Valério et al. (1997). During 2011/2012, 114 hybrids were evaluated in five consecutive experiments using randomized complete blocks with ten replications. The controls were $B$. decumbens $\mathrm{cv}$. Basilisk, B. brizantha cv. Marandu, Brachiaria spp. cv. BRS Ipyporã e Brachiaria spp. MulatoII for all experiments. During 2012/2013, another 259 hybrids were evaluated in seven consecutive experiments also in a complete randomized block design with four replications and the controls were $B$. decumbens $\mathrm{cv}$. Basilisk, $B$. brizantha $\mathrm{cv}$. Marandu, B. brizantha cv. BRS Paiaguás, Brachiaria spp. BRS cv. Ipyporã, Brachiaria spp. MulatoI e Brachiaria spp. MulatoII for all experiments. The variables evaluated were nymphal survival (NS), in percentage, and duration of nymphal period (DNP), in days. These experiments were preliminaries, and the confirmation of resistance will occur after other stages of selection, which are essential for the release of new pasture cultivars.

For the statistical analysis of TDM, an analysis of covariate for number of plants per plot for each clipping using the SAS statistical package (SAS Institute 2002) was done so as to correct for losses of plants as indicated in Vencovsky and Barriga (1992). With the corrected data for TDM and all other traits the data were then processed using a mixed model approach with the software SELEGEN REML/BLUP (Resende 2007a). An analysis for each clipping was initially done, since each trait was evaluated in several clippings per plot. Subsequently, based on the heterogeneity of residual variances evidenced by the variation in estimates of the individual heritabilities per clipping, the phenotypic data were standardized by multiplying the data of each trait in each clipping by the expression $\sqrt{h_{i k}^{2}} / \sqrt{\sqrt{h_{i}^{2}}}$ (Resende et al. 2008), in which $h_{i k}^{2}$ is the plant heritability for trait $i$ in 
clipping $k$ and $\bar{h}_{i}^{2}$ the average plant heritability of $k$ clippings for trait $i$. With the standardized data, combined analysis was performed, considering all clippings, according to the following statistical model:

$$
y^{\mathbf{p}}=X m+W b+Z g+Q p+T i+e
$$

where:

$y^{\mathrm{p}}$ : vector of standardized data;

$m$ : vector of the effects of the combination clippingreplication (fixed) added to the general mean;

$b$ : vector of the effects of blocks (random), where $\mathrm{b} \sim \mathrm{NMV}$ $\left(0, \mathrm{I} \sigma_{b}^{2}\right), \sigma_{b}^{2}$ is the variance associated to the blocks effects; $g$ : vector of the genotypic effect of hybrids (random), where $g \sim \operatorname{NMV}\left(0, \mathrm{I} \sigma_{g}^{2}\right) . \sigma_{g}^{2}$ is the variance associated to the effects of hybrids;

$p$ : vector of the effects of the permanent environment or plots (random), where $\mathrm{p} \sim \operatorname{NMV}\left(0, \mathrm{I} \sigma_{p}^{2}\right) . \sigma_{p}^{2}$ is the variance associated to the plot effects;

$i$ : vector of the effect of the interaction hybrids $\mathrm{x}$ clippings (random), where $\mathrm{i} \sim \operatorname{NMV}\left(0, \mathrm{I} \sigma_{g c}^{2}\right) . \sigma_{g c}^{2}$ is the component of variance associated to the effects of the interaction hybrids x clippings;

$e$ : vector of random errors, where e $\sim \operatorname{NMV}\left(0, \mathrm{I} \sigma_{e}^{2}\right)$;

$\mathrm{X}, \mathrm{W}, \mathrm{Z}, \mathrm{Q}$ e $\mathrm{T}$ : incidence matrices for $\mathrm{m}, \mathrm{b}, \mathrm{g}, \mathrm{p}$ and $\mathrm{i}$, respectively.

The estimation of the variance components and the prediction of the random effects, especially of the genotypic values associated to the hybrids were carried out using the REML/BLUP procedure (restricted maximum likelihood/ best linear unbiased prediction). The significance of the random effect was verified by the likelihood ratio test, (LRT) (Resende 2007b). The experimental precision was measured by means of the estimation of accuracy, as proposed by Resende and Duarte (2007). Furthermore, the heritability between genotype means $\left(h_{m}^{2}\right)$ and the genetic correlation among agronomic traits were estimated. Genetic correlations were estimated using model 102 of the SELEGEN REML/ BLUP software. The analyses of spittlebug resistance data also used SELEGEN REML/BLUP and the model 16 which considers groups of experiments with common treatments (controls). The effect of hybrids and block within experiments were considered random.

In order to verify the genetic progress with the selection of superior hybrids the gain with selection was estimated, using different intensities of selection $(10 \%, 5 \%$ e $2,5 \%)$ and also in relation to cv. Basilisk. For the selection of hybrids through breeding and gain for several traits simultaneously, on the rainy and dry seasons, the following selection index was adopted (Resende 2007b):

$$
I_{j}=\sum_{i=1}^{n} \hat{g}_{i j} \times w_{i} \times \frac{\mathbf{1}}{\hat{\sigma}_{g_{i}}}
$$

where:

$l_{j}$ : Index associated to the progeny $j$;

$\hat{g}_{\mathrm{ij}}$ : predicted genotypic value of the progeny $j$ for the trait $i$; $w_{i}$ : proportional importance or economic weight associated to trait $i$;

$\hat{\sigma}_{g i}:$ estimated standard genotypic deviation for the trait $i$.

The ranking of hybrids based on selection indices was done considering the agronomic traits TDM, LDM, $\% \mathrm{~L}$, LST and Reg, simultaneously. Index 1 was established with equal weights among traits, $20 \%$ for each, for the rainy season (100\% rain); Index 2: different weight among traits, where LDM and $\% \mathrm{~L}$ had $27.5 \%$ each and $15 \%$ for the others, for the rainy season (100\% rain); Index 3: equal weights for the traits, $20 \%$ for each for the dry season $(100 \%$ dry); Index 4: different weight among traits, where LDM and $\% \mathrm{~L} \mathrm{had} 27.5 \%$ each and $15 \%$ for the others, for the dry season (100\% dry); Index 5: equal weights of $10 \%$ for all traits, for the rain and dry seasons (50\% rain and 50\% dry); Index 6: different weight among traits, where LDM and $\% \mathrm{~L}$ had $13 \%$ each and the others had $8 \%$, for the rain and dry season ( $50 \%$ rain and $50 \%$ dry); Index 7 : equal weights for the traits, with $8 \%$ for each in the dry season and $12 \%$ for each in the rainy season (60\% rain and $40 \%$ dry); Index 8: different weight among traits, where LDM and $\% \mathrm{~L}$ had $11 \%$ each and $6 \%$ for the other traits in the dry season and $15 \%$ for the traits LDM and $\% \mathrm{~L}$ e $10 \%$ for the others in the rainy season (60\% rain and $40 \%$ dry).

The Spearman coefficient of correlation as presented by Ferreira (2005) and implemented in Proc Corr of the SAS program (SAS 2002) was used with the objective of checking the magnitude of alteration in the ranking of hybrids by the different indexes.

\section{RESULTS AND DISCUSSION}

Significant difference for the effect of hybrids was observed for all the agronomic traits and resistance to pasture spittlebugs through the maximum likelihood test $(p<0.01)$. This result indicates the presence of genetic variability among the hybrids of $B$. decumbens for all these traits which allows selection of superior hybrids for both groups of traits. The hybrids $\mathrm{x}$ clippings interaction was significant $(p<0.01)$ 
for all traits meaning that the behavior of hybrids was not coincident throughout the clippings. Significant estimates of $\sigma_{g c}^{2}(p<0.01)$ were also reported by Mendonça et al. (2013) on the agronomic evaluation of $50 \mathrm{~B}$. decumbens hybrids using six clippings (four in the rainy and two in the dry season). Accuracy varied from 0.72 to 0.99 for FGW and NS/DNP, respectively, considered by Resende and Duarte (2007) as of moderate to very high precision, thus conferring high confidence on the experimental results (Table 1). Similar accuracy values for agronomic traits were observed in progenies of $B$. humidicola evaluated by nine clippings (Figueiredo et al. 2012).

Heritability estimates between hybrid means $\left(h_{m}^{2}\right)$ varied from 0.52 to 0.84 for FGW and LSR, respectively and from 0.98 to 0.99 for spittlebug variables NS and DNP, respectively. For all traits, more than half of the variation observed between hybrids was due to genetic causes, demonstrating the potential for selecting genotypically superior hybrids. For NS and DNP, the heritability estimates between hybrids means (0.98 and 0.99) was of high magnitude, thus the number of replications and the strategy of analyzing groups of experiments with common treatments (controls) was adequate and guaranteed good experimental precision as proven by the estimates of accuracy.
It was possible to identify hybrids with superior performance compared to commercial cultivars considering predicted genotypic values (BLUP) of the hybrids, in the joint analysis of agronomic traits for all clippings and groups of experiments of resistance to spittlebugs. For FGW, TDM and LDM, cv. Basilisk was better than the majority of hybrids, with the exception of hybrid R041 which had higher BLUP for FGW, B006 and R041 for TDM and R041, R084 and R086 for LDM. For all other agronomic traits, cv. Basilisk was placed on the $194^{\text {th }}$ position for $\% \mathrm{~L}, 250^{\text {th }}$ for LSR and $207^{\text {th }}$ for Reg. Euclides et al. (1992) observed that the diet selected by animals on signalgrass pastures had $90 \%$ of green forage with a large portion of it comprised of leaf blades, thus the variables related to the leaf component such as $\% \mathrm{~L}$ and LSR are of great interest in the breeding of the species. Compared to the cultivars of B. brizantha, of greater production potential, only cv. Xaraés had higher BLUP for TDM, LDM and Reg, whereas compared to cv. Marandu and BRS Piatã, several hybrids of $B$. decumbens performed better for individual traits. For resistance to spittlebugs, of the 373 hybrids analyzed in the preliminaries trials, 109 had better performance than cv. Basilisk for NS and 201 for DNP, which denotes that hybrids that associate good agronomic performance to resistance to spittlebugs can be selected by further cycles of breeding. Furthermore,

Table 1. Deviance analysis (ANADEV), estimates of genotypic variance $\left(\hat{\sigma}^{2}\right)$, variance of hybrids x clippings interaction $\left(\hat{\sigma}^{2}\right)$, heritability between hybrid means $\left(h_{m}^{2}\right)$, accuracy and general mean for agronomic traits (field data) and spittlebug resistance (greenhouse data) of $B$. decumbens hybrids

\begin{tabular}{|c|c|c|c|c|c|c|c|c|}
\hline \multirow{2}{*}{ Effect/Parameter } & \multicolumn{2}{|c|}{ FGW } & \multicolumn{2}{|c|}{ TDM } & \multicolumn{2}{|c|}{$\% \mathrm{~L}$} & \multicolumn{2}{|c|}{ LDM } \\
\hline & Deviance $^{1}$ & $\mathrm{LTR}^{2}$ & Deviance & LTR & Deviance & LTR & Deviance & LTR \\
\hline Hybrids & 59521.17 & $83.94^{* *}$ & 59005.19 & $75.01^{* *}$ & 13347.10 & $36.08^{* *}$ & 31030.45 & $61.45^{\text {** }}$ \\
\hline Blocks & 59488.32 & $51.09^{* *}$ & 58976.54 & $46.36^{* *}$ & 13332.79 & $21.77^{* *}$ & 31000.46 & $31.46^{* *}$ \\
\hline Hybrids x clippings & 59556.20 & $118.97^{* *}$ & 59090.72 & $160.54^{* *}$ & 13394.70 & $83.68^{* *}$ & 31113.24 & $144.24^{* *}$ \\
\hline$\hat{\sigma}_{g}^{2}$ & $56322.58^{* *}$ & & $37992.98^{* *}$ & & $9.25^{* *}$ & & $17636.83^{* *}$ & \\
\hline$\hat{\sigma}_{g c}^{2}$ & $26505.92^{* *}$ & & $27077.79^{* *}$ & & $8.72^{* *}$ & & $11173.21^{* *}$ & \\
\hline Accuracy & 0.72 & & 0.76 & & 0.77 & & 0.73 & \\
\hline General Mean & 5081.76 & & 1208.06 & & 55.72 & & 732.44 & \\
\hline \multirow{2}{*}{ Effect/Parameter } & \multicolumn{2}{|c|}{ LSR } & \multicolumn{2}{|c|}{ Regrowth } & \multicolumn{2}{|c|}{ NS } & \multicolumn{2}{|c|}{ DNP } \\
\hline & Deviance & LTR & Deviance & LTR & Deviance & LTR & Deviance & LTR \\
\hline Hybrids & 5168.36 & $38.99^{* *}$ & 498.53 & $129.65^{* *}$ & 15396.27 & $80.28^{* *}$ & 6079.44 & $319.15^{* *}$ \\
\hline$\hat{\sigma}_{g c}^{2}$ & $0.04^{* *}$ & & $0.05^{* *}$ & & - & & - & \\
\hline$h_{m}^{2}$ & 0.84 & & 0.77 & & 0.98 & & 0.99 & \\
\hline Accuracy & 0.92 & & 0.88 & & 0.99 & & 0.99 & \\
\hline General Mean & 2.25 & & 2.26 & & 53.60 & & 32.72 & \\
\hline
\end{tabular}

${ }^{1}$ Deviance of the model adjusted without the referred effects; ${ }^{2}$ LRT: Likelihood ratio test; Agronomic traits: FGW (field green weight in kg/ha); TDM (total dry biomass production in $\mathrm{kg} / \mathrm{ha}$ ); LDM (leaf dry biomass production in $\mathrm{kg} / \mathrm{ha}$ ); \% (leaf percentage); LSR (leaf: stem ratio) and Reg (regrowth capacity). Traits associated to spittlebug resistance; NS (Nymphal survival, expressed in \%); DNP (duration of nymphal period in days). " $p<0.05$ and ${ }^{* * *} p<0.01$ by the $\chi^{2}$ test. 
strategies such as recurrent selection based on specific combining ability were recently adopted in order to increase the proportion of favorable alleles for both agronomic as well as insect resistance traits through selection cycles (Barrios et al. 2013).

Using the BLUP procedure, gains with selection (GS) can easily be attained from the hybrid BLUPs, since these express the predicted genotypic values, i.e., values already adjusted for the other effects in the model. The GS values using a selection intensity of $10 \%$ were $24.45 \%$ for FGW; $22.68 \%$ for TDM; $25.37 \%$ for $\mathrm{LDM} ; 6.61 \%$ for $\% \mathrm{~F} ; 31.84 \%$ for LSR; $22.19 \%$ for Reg; $18.44 \%$ for NS and $7.88 \%$ for DNP. GS values for a selection intensity of $5 \%$ were: $29.39 \%$ for FGW; 26.88\% for TDM; $8.04 \%$ for $\% \mathrm{~F} ; 30.01 \%$ for LDM; $47.02 \%$ for LSR; $28.43 \%$ for Reg; $23.48 \%$ for NS e $9.87 \%$ for DNP. Considering a selection intensity of $2.5 \%$ the GS were: $32.75 \%$ for FGW; $30.56 \%$ for TDM; $9.13 \%$ for $\% \mathrm{~F} ; 34.78 \%$ for LDM; $66.42 \%$ for LSR; $36.36 \%$ for Reg; $26.69 \%$ for NS e $11.21 \%$ for DNP thus expressive gains for all traits may be obtained when selecting superior hybrids. Comparing the best eight hybrids to cv. Basilisk the GS were $-4.73 \%$ for FGW; $-1.69 \%$ for TDM; $10.32 \%$ for $\% \mathrm{~F} ;-1.28 \%$ for LDM; $82.71 \%$ for LSR; $42.36 \%$ for Reg; $55.51 \%$ for NS and $19.16 \%$ for DNP. It important to note that several hybrids were better than the commercial variety for at least one evaluated trait and performed as cv. Basilisk for the other traits, thus it is possible to select better hybrids for certain traits without dramatically impairing the performance for other traits.

Among agronomic traits, the estimates of genetic correlation between pairs TDM-LDM (0.93) and \%L-LSR $(0.61)$ were positive and of high magnitude, so selecting for high biomass production will also select for high leaf production, good percentage of leaves and leaf: stem ratio. The effect of the correlation may be due to the action of a gene over one or more traits simultaneously or to genetic linkage (Ramalho et al. 2005). Another association that deserves attention is the positive and high genetic correlation $(0.95)$ between FGW and TDM. For practical purposes, this association is interesting since the selection based on FGW, which is measured in the field, will match the selection for TDM without the need for sampling for TDM determination. Therefore, the selection for a large number of genotypes could be initially done using only FGW, instead of TDM thus simplifying evaluation and cutting time. Afterwards, the pre-selected genotypes would be re-evaluated for all agronomic traits, including leaf blade components, with a larger number of replications. Furthermore, the indirect initial selection for FGW also brought about an increase in LDM $(r=0.92)$ which is extremely desirable (Table 2$)$.

To rank and select superior hybrids selection indexes were used, considering all traits simultaneously. The criteria for index elaboration was the establishment of equal weights or different weights between traits and equal weights or different weights rainy or dry seasons, just dry or just rainy season (see methods). Higher value weights were assigned to traits related to the leaf component, since those have greater impact on animal performance due to their greater nutritive value compared to stems (Mendonça et al. 2013). The ranking of hybrids considering just the rainy season was quite similar in the Indexes 1 and 2, indicating that the fact of assigning equal weights or different between the traits did not influence the selection of the best hybrids. This same association was observed for the dry period between the Indexes 3 and 4. This result is corroborated when comparing the Spearman correlation coefficient between the Indexes $1 \times 2$ and $3 \times 4$, with estimates of 0.99 for both correlations. On the other hand, on Indexes 5 and 6 which have equal weights for the seasons $(50 \%$ rainy and $50 \%$ dry), assigning different weights to the traits (Index 6) influenced the classification of hybrids when compared with the Index 5 (equal weights for the traits), with estimated correlation between the Indexes 5 $\mathrm{x} 6$ of 0.63 . This association, however was not observed between indexes 7 and 8 (60\% rainy and $40 \%$ dry), in which assigning different weight to the traits did not influence the classification of hybrids, which can be verified by the correlation estimated between these indexes of greater

Table 2. Estimates of genetic correlations among agronomic traits obtained based on the evaluation of hybrids of Brachiaria decumbens, using seven clippings

\begin{tabular}{|c|c|c|c|c|c|c|}
\hline & FGW $^{1}$ & TDM & $\% \mathrm{~L}$ & LDM & LSR & REGROWTH \\
\hline FGW & 1.00 & $0.95^{* * *}$ & $0.30^{* * *}$ & $0.92^{* *}$ & $-0.13^{*}$ & $0.41^{* * *}$ \\
\hline TDM & & 1.00 & $0.19^{* *}$ & $0.93^{* *}$ & $-0.19^{* * *}$ & $0.35^{* *}$ \\
\hline$\% \mathrm{~L}$ & & & 1.00 & $0.44^{* * *}$ & $0.61^{* *}$ & $0.57^{* * *}$ \\
\hline LDM & & & & 1.00 & -0.02 & $0.48^{* * *}$ \\
\hline LSR & & & & & 1.00 & $0.34^{* *}$ \\
\hline REGROWTH & & & & & & 1.00 \\
\hline
\end{tabular}

${ }^{1} \mathrm{FGW}$ (field green weight in $\mathrm{kg} / \mathrm{ha}$ ); TDM (total dry biomass production in $\mathrm{kg} / \mathrm{ha}$ ); LDM (leaf dry biomass production in $\mathrm{kg} / \mathrm{ha}$ ); \%L (leaf percentage); LSR (leaf: stem ratio) and Reg (regrowth capacity). ${ }^{*} p<0.05$ and ${ }^{* * *} p<0.01$ by the $t$ test. 
magnitude (0.99). In general assigning different weights to the traits did not drastically affect the classification of genotypes (Tables 3 e 4 ).

Another important point to mention is the assigning weights to the different seasons when considering equal weights for all traits (indexes $5 \times 7$ ) or different weights to the traits (indexes $6 \times 8$ ). Here, assigning greater weights to the rainy season $(60 \%)$ did not drastically change the classification of hybrids when compared to the index with equal weights between season and traits (indexes $5 \times 7$ ). However, in the case of assigning different weight to traits, the choice of greater weight to the rainy season (indexes $6 \times 8$ ) caused changes in the classification (Tables 3 e 4).

Independently of the index adopted, several hybrids were superior to the commercial B. decumbens. Cv. Basilisk was in $89^{\text {th }}$ position on Index $1,87^{\text {th }}$ on Index 2 ; $24^{\text {th }}$ on Index $3 ; 21^{\text {st }}$ on Index $4 ; 50^{\text {th }}$ on Index $5 ; 15^{\text {th }}$ on Index $6 ; 60^{\text {th }}$ on Index 7 and $54^{\text {th }}$ on Index 8 . Considering indexes 5 and 7 , which account for rainy and dry seasons simultaneously and equal weights for all traits, 49 and 59 hybrids were better than cv. Basilisk, respectively for the agronomic traits. Furthermore, considering the traits related to resistance to spittlebugs, all hybrids listed on Table 3 had lower NS and greater DNP compared to cv. Basilisk with the exception of hybrids R041, R081, R120,

Table 3. Rank of the ten better hybrids of $B$. decumbens $(\mathrm{Hyb})$ and of controls ${ }^{\mathrm{a}}$ on the basis of the indexes of selection ${ }^{\mathrm{b}}$ using the predicted genotypic values for the agronomic traits

\begin{tabular}{|c|c|c|c|c|c|c|c|c|c|c|c|}
\hline \multicolumn{3}{|c|}{ Index 1} & \multicolumn{3}{|c|}{ Index 2} & \multicolumn{3}{|c|}{ Index 3} & \multicolumn{3}{|c|}{ Index 4} \\
\hline Rank & Hyb & Index & Rank & Hyb & Index & Rank & Hyb & Index & Rank & Hyb & Index \\
\hline 1 & Xaraés & 14.15 & 1 & Xaraés & 15.43 & 1 & Xaraés & 59.47 & 1 & R041 & 73.07 \\
\hline 2 & A005 & 12.77 & 2 & S016 & 13.90 & 2 & R041 & 59.28 & 2 & Xaraés & 73.01 \\
\hline 4 & R023 & 12.54 & 4 & B013 & 13.66 & 4 & B013 & 59.06 & 4 & B013 & 72.76 \\
\hline 5 & R033 & 12.47 & 5 & A005 & 13.60 & 5 & B001 & 59.00 & 5 & B001 & 72.56 \\
\hline 8 & S030 & 12.32 & 8 & S030 & 13.48 & 8 & R084 & 58.62 & 8 & R084 & 72.42 \\
\hline 9 & B001 & 12.16 & 9 & R041 & 13.29 & 9 & T005 & 58.61 & 9 & B014 & 72.34 \\
\hline 10 & B011 & 12.07 & 10 & X079 & 13.27 & 10 & R193 & 58.60 & 10 & T005 & 72.27 \\
\hline 89 & Basilisk & 10.96 & 87 & Basilisk & 12.26 & 24 & Basilisk & 58.27 & 21 & Basilisk & 71.97 \\
\hline 21 & Marandu & 11.75 & 26 & Marandu & 12.95 & 31 & Marandu & 58.16 & 27 & Marandu & 71.86 \\
\hline 1 & Xaraés & 36.81 & 1 & R084 & 27.63 & 1 & Xaraés & 32.28 & 1 & Xaraés & 36.12 \\
\hline 2 & R023 & 35.89 & 2 & R041 & 27.52 & 2 & R023 & 31.22 & 2 & R023 & 35.04 \\
\hline 3 & S016 & 35.75 & 3 & R081 & 27.48 & 3 & S016 & 31.14 & 3 & S016 & 34.96 \\
\hline 4 & B013 & 35.75 & 4 & R086 & 27.40 & 4 & B013 & 31.08 & 4 & B013 & 34.95 \\
\hline 5 & R041 & 35.64 & 5 & Xaraés & 27.38 & 5 & R033 & 30.92 & 5 & R041 & 34.85 \\
\hline 6 & B001 & 35.58 & 6 & R025 & 27.36 & 6 & R041 & 30.92 & 6 & B001 & 34.67 \\
\hline 7 & R033 & 35.53 & 7 & T046 & 27.34 & 7 & B001 & 30.90 & 7 & R033 & 34.63 \\
\hline 8 & S030 & 35.42 & 8 & T016 & 27.32 & 8 & S030 & 30.80 & 8 & R084 & 34.53 \\
\hline 9 & R084 & 35.23 & 9 & R168 & 27.32 & 9 & R084 & 30.55 & 9 & S030 & 34.53 \\
\hline 10 & B014 & 35.20 & 10 & X072 & 27.30 & 10 & B014 & 30.54 & 10 & B014 & 34.47 \\
\hline
\end{tabular}

aControls: B. decumbens cv. Basilisk, B. brizantha cv. Marandu, B. brizantha cv. Piatã, B. brizantha cv. Xaraés;

'Index 1: agronomic traits (TDM, LDM, \%L, LSR, Reg) with equal economic weights, for the rainy season clippings (100\% rainy); Index2: agronomic traits (TDM, LDM, $\%$ L, LSR, Reg) with different economic weights, for the rainy season clippings (100\% rainy); Index 3: agronomic traits (TDM, LDM, \%L, LSR, Reg) with equal economic weights, for the dry season clippings ( $100 \%$ dry); Index 4: agronomic traits (TDM, LDM, \%L, LSR, Reg) with different economic weights, for the dry season clippings (100\% dry); Index 5: agronomic traits (TDM, LDM, \%L, LSR, Reg) with equal economic weights, for the dry and wet seasons (50\% dry and 50\% rain); Index 6: agronomic traits (TDM, LDM, \%L, LSR, Reg) with different economic weights, for the dry and rain season clippings (50\% rain and 50\% dry); Index 7: agronomic traits (TDM, LDM, $\%$ L, LSR, Reg) with equal economic weights, for the dry and wet seasons (60\% rain and 40\% dry); Index 8: agronomic traits (TDM, LDM, \%L, LSR, Reg) with different economic weights, for the dry and rain season clippings (60\% rain and $40 \%$ dry). 
Genetic parameters and selection of Brachiaria decumbens hybrids for agronomic traits and resistance to spittlebugs

Table 4. Spearman coefficient of correlation amongst different indexes used for ranking the hybrids

\begin{tabular}{|c|c|c|c|c|c|c|c|c|}
\hline & Index 1 & Index 2 & Index 3 & Index 4 & Index 5 & Index 6 & Index 7 & Index 8 \\
\hline Index 1 & 1.00 & $0.99^{* *}$ & $0.70^{* *}$ & $0.69^{* *}$ & $0.93^{* *}$ & $0.58^{* *}$ & $0.96^{* *}$ & $0.95^{* *}$ \\
\hline Index 2 & & 1.00 & $0.69^{* * *}$ & $0.69^{* * *}$ & $0.92^{* *}$ & $0.61^{* * *}$ & $0.95^{* * *}$ & $0.95^{* *}$ \\
\hline Index 3 & & & 1.00 & $0.99^{* *}$ & $0.90^{* *}$ & $0.61^{* *}$ & $0.87^{* * *}$ & $0.87^{* *}$ \\
\hline Index 5 & & & & & 1.00 & $0.63^{* * *}$ & $0.99^{* * *}$ & $0.99^{\text {*** }}$ \\
\hline Index 6 & & & & & & 1.00 & $0.63^{* *}$ & $0.67^{* *}$ \\
\hline
\end{tabular}

" $p<0.05$ and ${ }^{* * *} p<0.01$ by the $t$ test.

S030 and T005 for DNP, corroborating the possibility of selecting hybrids that show better agronomic performance and resistance to spittlebugs simultaneously. Sexual hybrids identified in this work were recombined in an intrapopulacional recurrent selection scheme to improve the sexual population whereas the superior apomictic hybrids, which are candidates to new cultivars were included in the next phases of the breeding program.

\section{ACKNOWLEDMENTS}

The authors thank the Association for the Promotion of Research in Forage Breeding (UNIPASTO), the National Scientific and Technological Development Commission (CNPq) for the financial support for the carrying out of the experiments and the Federal Agency for the Support and Evaluation of Graduate Education (CAPES), for the granting of a scholarship.

\section{Parâmetros genéticos e seleção de híbridos de Brachiaria decumbens para caracteres agronômicos e de resistência às cigarrinhas das pastagens}

Resumo - O objetivo deste trabalho foi estimar parâmetros genéticos para caracteres agronômicos e de resistência às cigarrinhasdas-pastagens em hibridos de Brachiaria decumbens e selecionar os de melhor desempenho. Trezentos e vinte e quatro hibridos foram avaliados em campo para caracteres agronômicos e em casa de vegetação para resistência às cigarrinhas-das-pastagens. Observouse existência de variabilidade genética entre os hibridos para todos os caracteres analisados. As estimativas de herdabilidade entre médias de genótipos foram superiores a 0,52 para todos os caracteres agronômicos e de 0,98 para sobrevivência ninfal e 0,99 para duração do período ninfal. Híbridos com melhor desempenho em relação a cultivar Basilisk foram identificados para cada caráter individualmente e conjuntamente por meio de indices de seleção. A atribuição de pesos diferentes entre os caracteres nos índices de seleção não alterou significativamente o ranqueamento dos híbridos. Híbridos superiores foram selecionados para as próximas etapas do programa de melhoramento.

Palavras-chaves: Apomixia, melhoramento de forrageiras, seleção recorrente, indice de seleção.

\section{REFERENCES}

Barrios SCL, Valle CB, Alves GFA, Resende RMS and Jank L (2013) Reciprocal recurrent selection in the breeding of Brachiaria decumbens. Tropical Grasslands - Forrajes Tropicales 1: 52-54.

Basso KC, Resende RMS, Valle CB, Gonçalves MC and Lempp B (2009) Avaliação de acessos de Brachiaria brizantha Stapf e estimativas de parâmetros genéticos para caracteres agronômicos. Acta Scientiarum Agronomy 31: 17-22.

Empresa Brasileira de Pesquisa Agropecuária (1999) Sistema brasileiro de classificação de solos. EMBRAPA-SPI, Brasília, 412p.

Euclides VPB, Macedo MCM and Oliveira MP (1992) Avaliação de diferentes métodos de amostragem para se estimar o valor nutritivo de forragens sob pastejo. Revista Brasileira de Zootecnia 21: 691-701.

Ferreira DF (2005) Estatística básica. Editora UFLA, Lavras, 664 p.
Figueiredo UJ, Nunes JAR and Valle CB (2012) Estimation of genetic parameters and selection of Brachiaria humidicola progenies using a selection index. Crop Breeding and Applied Biotechnology 12: 237-244.

Jank L, Barrios SC, Valle CB, Simeão RM and Alves GF (2014) The value of improved pastures to Brazilian beef production. Crop and Pasture Science 65: 1132 - 1137.

José MR (2012) Forrageiras: uma grande parceira para o agronegócio. Associação Brasileira de Sementes e Mudas, Anuário 2012, p. 22

Keller-Grein G, Maass BL and Hanson J (1996) Natural variation in Brachiaria and existing germplasm collections. In Miles JW (ed.) Brachiaria: biology, agronomy, and improvement. CIAT, Cali, p. 16-42.

Lapointe SL, Serrano MS, Arango GL, Sotelo G and Cordoba F (1992) Antibiosis to spittlebugs (Homoptera: Cercopidae) in accessions 
RG Mateus et al.

of Brachiaria. Journal of Economic Entomology 85: 1485-1490.

Lascano CE and Euclides VPB (1996) Nutritional quality and animal production of Brachiaria pastures. In Miles JW (ed.) Brachiaria: biology, agronomy, and improvement. CIAT, Cali, p. 106-123.

Mendonça SA, Barrios SCL, Figueiredo UJ, Alves GF and Valle CB (2013) Agronomic and nutritional evaluation of intraspecific crosses in Brachiaria decumbens. Tropical Grasslands - Forrajes Tropicales 1: 103-105.

Ramalho MAP (2005) Experimentação em genética e melhoramento de plantas. Editora UFLA, Lavras, 326p.

Resende MDV (2007a) Software SELEGEN - REML/BLUP: Sistema estatístico e seleção computadorizada via modelos lineares mistos. Embrapa Florestas, Colombo, 359p.

Resende MDV (2007b) Matemática e estatística na análise de experimentos e no melhoramento genético. Embrapa Florestas, Colombo, 561p.

Resende MDV and Duarte JB (2007) Precisão e controle de qualidade em experimentos de avaliação de cultivares. Pesquisa Agropecuária Tropical 37: 182-194.

Resende MDV, Resende RMS and Jank L (2008) Experimentação e análise estatística no melhoramento de forrageiras. In Resende RMS, Valle CB, Jank L (Org) Melhoramento de Forrageiras Tropicais. Embrapa Gado de Corte, Campo Grande, p. 195-287.

Simioni C and Valle CB (2009) Chromosome duplication in Brachiaria (A.Rich.) Stapf allows intraspecific crosses. Crop Breeding and Applied Biotechnology 9: 328 - 334.

SAS - Statistical Analysis System (2002) SAS/STAT user's guides Version 9. SAS Institute, Cary.

Valério JR, Lapointe SL, Kelemu S, Fernandes CD and Morales FJ (1996) Pests and diseases of Brachiaria species. In Miles JW (ed.) Brachiaria: biology, agronomy, and improvement. CIAT, Cali, p. $87-105$.

Valério JR, Jeller H and Peixer J (1997) Seleção de introduções do gênero Brachiaria resistentes à cigarrinha Zulia entreriana (Berg) (Homoptera: Cercopidae). Anais da Sociedade Entomológica do Brasil 26: 383-387.

Valle CB, Jank L and Resende RMS (2009) O melhoramento de forrageiras tropicais no Brasil. Revista Ceres 56: 460-472.

Vencovsky R and Barriga P (1992) Genética Biométrica no fitomelhoramento. Revista Brasileira de Genética, Ribeirão Preto, 496p. 